\title{
What is the response profile of deciduous pulp fibroblasts stimulated with E. coli LPS and E. faecalis LTA?
}

Bella Luna Colombini-Ishikiriama', Thiago Jose Dionisio', Thais Francini Garbieri', Rafaela Alves da Silva², Maria Aparecida Andrade Moreira Machado ${ }^{3}$, Sandra Helena Penha de Oliveira ${ }^{4}$, Vanessa Soares Lara ${ }^{2}$, Andrew Seth Greene ${ }^{5}$ and Carlos Ferreira Santos ${ }^{1 *}$ (D)

\begin{abstract}
Background: Oral fibroblast immunological responses to bacterial stimuli are well known. However, there are few studies about pulp fibroblasts from deciduous teeth (HDPF) responses, which are important for the treatment of pulp infections in children. The aim of this study was to evaluate expression and production of inflammatory cytokines and chemokines by HDPF when challenged with bacterial antigens normally present in advanced caries lesions.

Methods: Triplicate HDPF from 4 children ( $n=4 ; 2$ boys and 2 girls) were cultured by explant technique and challenged or not with Escherichia coli lipopolysaccharide/1 $\mathrm{\mu g} / \mathrm{mL}$ (EcLPS) or Enterococcus faecalis lipoteichoic acid/ $1 \mathrm{\mu g} / \mathrm{mL}$ (EfLTA) for 6 and $24 \mathrm{~h}$. Most of published studies employed immortalized cells, i.e., without checking possible gender and genetic variables. mRNA expression and protein production were evaluated by RT-qPCR and ELISA MILLIPLEX ${ }^{\oplus}$, respectively, for Interleukin (IL)-1a, IL-1ß, IL-2, IL-4, IL-6, IL-8, IL-10, IL-12, IL-17, Chemokine C-C motif ligand 2/monocyte chemoattractant protein 1 (CCL2/MCP-1), Chemokine C-C motif ligand 3/macrophage inflammatory protein 1-alpha (CCL3/MIP1-a), Chemokine C-C motif ligand 5/ regulated on activation, normal T cell expressed and secreted (CCL5/RANTES), C-X-C motif chemokine 12/ stromal cell-derived factor 1 (CXCL12/SDF-1), Tumor Necrosis Factor-alpha (TNF-a), Interferon-gamma (IFN ץ), Vascular Endothelial Growth Factor (VEGF), Colony stimulating factor 1 (CSF-1) and Macrophage colony-stimulating factor (M-CSF).
\end{abstract}

Results: EcLPS increased IL-1a, IL-1 $\beta$, IL-8, CCL2, CCL5, TNF- $a$ and CSF-1 mRNA and protein levels while EfLTA was only able to positively regulate gene expression and protein production of IL-8.

Conclusion: The results of the present study confirmed our hypothesis, since pulp fibroblasts from deciduous teeth are capable of increasing gene expression and protein production after being stimulated with EcLPS and EfLTA.

Keywords: Cytokines, Dental pulp, Fibroblasts and lipopolysaccharide

\footnotetext{
*Correspondence: cfsantos@fob.usp.br

${ }^{1}$ Department of Biological Sciences, Bauru School of Dentistry, University of São Paulo, Bauru, SP, Brazil

Full list of author information is available at the end of the article
}

(c) The Author(s). 2020 Open Access This article is licensed under a Creative Commons Attribution 4.0 International License, which permits use, sharing, adaptation, distribution and reproduction in any medium or format, as long as you give appropriate credit to the original author(s) and the source, provide a link to the Creative Commons licence, and indicate if changes were made. The images or other third party material in this article are included in the article's Creative Commons licence, unless indicated otherwise in a credit line to the material. If material is not included in the article's Creative Commons licence and your intended use is not permitted by statutory regulation or exceeds the permitted use, you will need to obtain permission directly from the copyright holder. To view a copy of this licence, visit http://creativecommons.org/licenses/by/4.0/ The Creative Commons Public Domain Dedication waiver (http://creativecommons.org/publicdomain/zero/1.0/) applies to the data made available in this article, unless otherwise stated in a credit line to the data. 


\section{Background}

Pulp tissue of deciduous teeth is often exposed to bacterial challenges arising from untreated carious lesions. The products of proliferation and metabolic activity of biofilm microorganisms that colonize these lesions degrade the enamel and dentin mineralized tissues reaching the connective tissue located at the center of the tooth. During this process, proliferation and metabolic activity products of the microorganisms and dentin matrix bioactive molecules are released and defunds towards dentinal tubules starting host protective events including antibacterial, immune, and inflammatory responses against this bacterial invasion $[1,2]$.

After been recognized by odontoblasts cell layer by Toll-like receptor (TLR) family, the Pathogen-Associated Molecular Patterns (PAMPs), presented in its cell membrane, starts the effector phase of innate immune response $[3,4]$. The activation of TLR upregulates innate immunity effectors, including production of antimicrobial agents and proinflammatory cytokines and chemokines $[5,6]$, with the objective of recruit and activate cells present in tissue resident and blood, to eliminate pathogens and allow repair $[7,8]$.

Fibroblasts are the most abundant cells in the pulp and can play immunoinflammatory roles after recognition of lipopolysaccharide (LPS) via TLR 4 and lipoteichoic acid (LTA) via TLR2. TLRs act as sentinel receptors and their stimulation leads to activation of transcription factors such as nuclear factor-k B and interferon regulatory factors, which promote the transcription of proinflammatory cytokines and other proteins that promote host defenses [9]. In humans, the are 11 different TLRs that recognize different molecules native to bacteria, viruses, fungi and protozoa [10, 11]. In view of the presence of TLRs in fibroblasts, stimuli with LPS from Escherichia coli and LTA from Enterococcus faecalis were used to ascertain the behavior of pulp fibroblasts from deciduous teeth.

Studies have shown that pulp tissues of inflamed permanent teeth have increased levels of various cytokines such as IL-1 $\beta[12,13]$, IL-17 [14], Il-6 and IL-8 $[13,15,16]$, TNF- $\alpha$ [17], MIP-3 $\alpha$ [18] and CXCL10 [19]. Cultured fibroblasts derived from permanent pulp tissue also can produce cytokines/chemokines like IL-1 $\beta$, IL-6, IL-8, IL-17, IL-23, CCL3, and CXCL12 when challenged by other cytokines $[14,20]$ or by microbial components $[13,16,21-23]$.

However, studies of the expression/production of these cytokines and chemokines in pulp tissues or even in cultured cells of deciduous pulps are scarce in the literature. It is known that Human Deciduous Pulp Fibroblasts (HDPF) are capable of producing cytokines such as IL-1 $\beta$ and IL-8 against pulp capping materials [24], CCL3 and CXCL12 in response to stimulation with LPS and LTA $[22,23]$. It is of fundamental importance to increase the knowledge on the role of fibroblasts in the expression/production of these molecules.

Our hypothesis is that, challenged with antigens, pulp fibroblasts from deciduous teeth may produce many other inflammatory cytokines. The purpose of the present study was to evaluate the expression and production of inflammatory cytokines and chemokines by HDPF when challenged by Escherichia coli lipopolysaccharide or Enterococcus faecalis lipoteichoic acid.

\section{Methods \\ Cell culture}

Human pulp fibroblasts were obtained from 6 teeth indicated for extraction due to orthodontic reasons, which were donated by 4 children ( 2 boys and 2 girls) aged $7-$ 11 years. After their legal parents or guardians and children's written consent, teeth were donated. Ethical approval was obtained from the Ethics Committee for Human Research of the Bauru School of Dentistry, University of São Paulo (CAAE: 44739015.0.0000.5417).

Pulp tissue was removed in aseptic conditions and cultured by using an explant technique as described previously [23]. Tissues were fragmented and incubated for cell growth in Dulbecco's modified Eagle medium (DMEM) (Invitrogen, Life Technologies Corp, Carlsbad, CA) supplemented with $10 \%$ fetal bovine serum (FBS) (Gibco, Invitrogen, Carlsbad, $\mathrm{CA})$ and antibiotics $(100 \mathrm{mg} / \mathrm{mL}$ penicillin, $100 \mathrm{mg} / \mathrm{mL}$ streptomycin, $0.5 \mathrm{mg} / \mathrm{mL}$ amphotericin B; Invitrogen). Cultures were maintained at $37^{\circ} \mathrm{C}$ in a humidified atmosphere of $5 \% \mathrm{CO}_{2}$ and $95 \%$ air. Cells were used between the fourth and eighth passages.

\section{Cell viability}

The concentrations of the antigens Escherichia coli lipopolysaccharide $/ 1 \mu \mathrm{g} / \mathrm{mL}$ (EcLPS) or Enterococcus faecalis lipoteichoic acid $/ 1 \mu \mathrm{g} / \mathrm{mL}$ (EfLTA) used in this study were previously tested about their toxicity under HDPF and did not show any effect in cell viability after $24 \mathrm{~h}$ of stimulus [23]. The phenotypic characterization of fibroblasts was carried out according to previously publication [23].

\section{Fibroblast stimulation}

Cells were trypsinized and plated at a concentration of $5 \times 10^{4}$ cells/well in 24-well plates. After $24 \mathrm{~h}$ to allow cellular attachment, medium alone (DMEM 1\% FBS) (Controls) or containing Escherichia coli lipopolysaccharide $/ 1 \mu \mathrm{g} / \mathrm{mL}$ (EcLPS) (L4391; Sigma-Aldrich, St Louis, MO) or Enterococcus faecalis lipoteichoic acid/ $1 \mu \mathrm{g} / \mathrm{mL}$ (EfLTA) (L4015; Sigma-Aldrich) was added to the cells in triplicate, according to our previous studies $[21,22,25]$.

After the experimental times of 6 or $24 \mathrm{~h}$, the supernatant and cells were collected and analyzed by enzymelinked immunosorbent assay (ELISA MILLIPLEX ${ }^{\oplus}$ ) and 
quantitative real-time polymerase chain reaction (qPCR), respectively.

\section{Real-time qPCR}

Total RNA was obtained directly from cells using RNAextraction columns kit (PureLink ${ }^{\text {Th }}$ RNA Mini Kit, Ambion, Thermo Fisher Scientific, Waltham, MA) according to the manufacturer's instructions. The quantity and purity of RNA extracted were analyzed using a spectrophotometer Nanodrop 1000 (Thermo Fisher Scientific). RNA was treated with DNAse (gDNA wipeout; Qiagen) and processed using the High Capacity cDNA Reverse Transcription Kit (Applied Biosystems, Thermo Fisher Scientific). qPCR was performed using the TaqMan system for qPCR and proprietary 20x FAM and MGB dye labeled probe-primer mix listed in Supplementary Table 1. All experiments were performed in a Real Time PCR System (Viia 7, Applied Biosystems, Thermo Fisher Scientific) using the comparative cycle threshold $(\mathrm{Ct})$ method $(\Delta \Delta \mathrm{Ct})$ as previously described [26]. mRNA expression of all the target genes were normalized to the RPL13A reference gene (Supplementary Table 1).

\section{Cytokine/chemokine detection in fibroblasts supernatants by ELISA MILLIPLEX ${ }^{\circledR}$}

ELISA MILLIPLEX ${ }^{\oplus}$ was performed to detect in supernatants of deciduous pulpal fibroblasts cultures the presence of 18 Cytokine/Chemokine, using the HCYTOMAG-60 K ELISA MILLIPLEX Kit (Cat.\# HCYTOMAG-60 K, Millipore, SIGMA) according to the manufacturer's protocol (Supplementary Table 2).

Briefly, 96-well plates were previously washed, in a shaker for $10 \mathrm{~min}\left(20-25^{\circ} \mathrm{C}\right)$, with wash buffer solution $(200 \mu \mathrm{L})$ before being dried and receiving $25 \mu \mathrm{L}$ of standard or controls into appropriate wells and assay buffer $(25 \mu \mathrm{L})$ to samples wells. Then, the same volume of DMEM $(25 \mu \mathrm{L})$ was added to the background, standards and control wells and $25 \mu \mathrm{L}$ of supernatants samples were added to the appropriate wells. In sequence, Mixing Bottle was vortexed and $25 \mu \mathrm{L}$ of Mixed Beads (mix of 18 target beads) were added to the wells and incubated, under agitation on a plate shaker, wrapped with a foil, overnight at $4{ }^{\circ} \mathrm{C}$.

After the incubation period, the well contents were gently removed and the plate was washed twice, with wash buffer solution $(200 \mu \mathrm{L})$, under agitation for $30 \mathrm{~s}$ and the aid of a magnetic plate washer $(60 \mathrm{~s})$. Then, $25 \mu \mathrm{L}$ of Detection Antibodies were added to the wells, and incubated, under agitation, wrapped with a foil, for $1 \mathrm{~h}$ at $20-25^{\circ} \mathrm{C}$.

The wells then received $25 \mu \mathrm{L}$ of streptavidinphycoerythrin and the plate was covered with a foil and incubated under agitation for $30 \mathrm{~min}$ at $20-25^{\circ} \mathrm{C}$. After this period, well contents were gently removed and the plate was washed twice, with wash buffer solution $(200 \mu \mathrm{L})$, under agitation for $30 \mathrm{~s}$ and the aid of a magnetic plate washer $(60 \mathrm{~s})$. Finally, $150 \mu \mathrm{L}$ of Sheath Fluid were added to all wells, the beads were resuspended on a plate shaker for $5 \mathrm{~min}$ and the plate ran on LUMINEX $200^{\mathrm{Tm}}$ for the detection of target cytokines/chemokines amounts in $\mathrm{pg} / \mathrm{mL}$.

\section{Statistical analysis}

Statistical analysis was performed with GraphPad Prism 6.0 software (GraphPad Prism 6.0, GraphPad Software, San Diego, CA, USA). Since all data were parametric, a nonpaired $\mathrm{t}$ test was used, observing the differences between the stimulated group in relation to the respective control in the same period of evaluation. Differences were identified using significance level set at 95\% $(p<0.05)$.

\section{Results}

Phenotypic characterization of fibroblasts

Deciduous Dental Pulp Fibroblasts were isolated and cultured as previously described [22, 23]. Positivity for Fibroblast Surface Protein- 1 (FSP-1) indicated their fibroblastic phenotype, as shown in Fig. 1.

\section{Cytokine/chemokine mRNA expression in deciduous pulp fibroblasts challenged by ECLPS and EfLTA}

mRNA evaluation of the cytokine/chemokine profile produced by HDPF challenged by EcLPS and EfLTA $(1 \mu \mathrm{g} / \mathrm{mL} ; 6$ and $24 \mathrm{~h})$ is described in Fig. 2.

Among the 18 targets studied, six of them were not expressed and did not suffer alteration in the expression when stimulated by both bacterial antigens - IL-2, IL10, IL-17, IL-18, CCL3 and INF- $\lambda$ (data not show).

However, 12 targets had mRNA expression detected in HDPF (Fig. 2) and the challenge generated by the presence of bacterial antigens showed a different behavior in the responses between EcLPS and EfLTA. EcLPS challenge was able to positively regulate the expression of the target genes of various cytokines studied - IL-1 $\alpha$, IL$1 \beta$, IL-8, CCL2, CCL5 TNF- $\alpha$ and CSF-1 (Fig. 2 A, B, E, G, H, J, L), whereas EfLTA was only able to positively regulate gene expression of IL-8 (Fig. 2E).

\section{Cytokine/chemokine secretion in supernatants of deciduous pulp fibroblasts challenged by ECLPS and EfLTA}

The same behavior observed in the evaluation of mRNA expression for cytokines/chemokines was observed when evaluating the protein presence in the supernatants of HPFD cultures stimulated or not by EcLPS and EfLTA. Lipopolysaccharide from Escherichia coli statistically stimulated the production of some cytokines and chemokines, being more evident in the evaluation period of 6 h (IL-1 $\beta$, IL-4, IL-8, IL-10, IL-12p70 (Fig. 3 - B, D, F, 


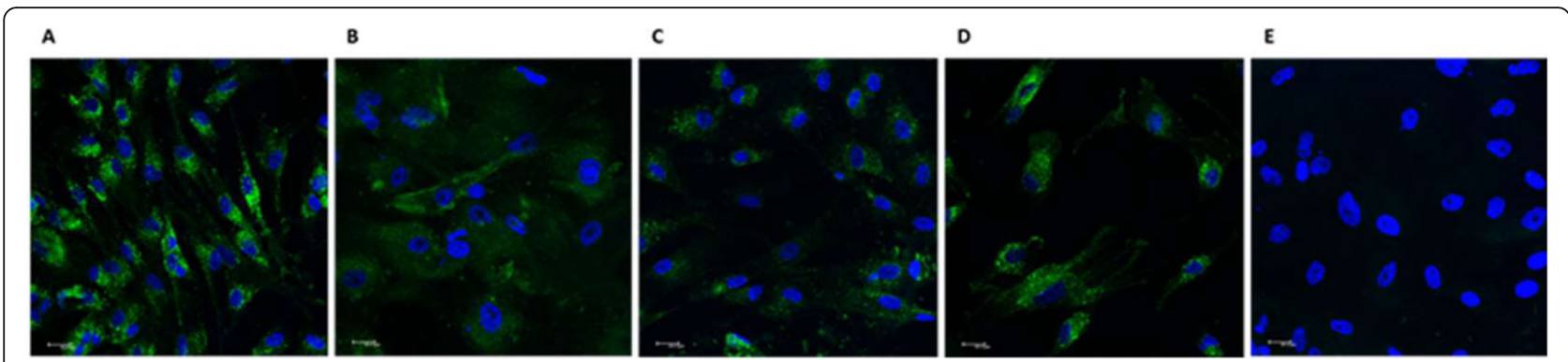

Fig. 1 - Phenotypic characterization of HDPF by Fibroblast Surface Protein (FSP) staining. HDPF from 4 different patients (A, B, C and D) were plated $\left(10^{4}\right.$ cells/well) and showed positive staining for FSP-1 protein (green). Cell nuclei were stained with DAPI- blue (4',6- diamidino-2phenylindole dihydrochloride). E - negative control. Images captured by a confocal microscope (TCS model, SPE, Leica ${ }^{\oplus}$, Mannheim, Germany). Scale bars - $20 \mu \mathrm{m}$

G, H), G-CSF, GM-CSF and INF- $\lambda$ (Fig. 4 - C, D, F) as compared to the 24-h period (IL-4, IL-8 and GM-CSF) (Figs. 3B, F and 4C). EfLTA also was only capable to upregulate the production of IL-8, in both experimental periods (Fig. 3F).

\section{Discussion}

Immune inflammatory response of pulp tissue from permanent teeth to the installation and progression of carious lesions has been studied over the last years. Among the events involved in this response against the various pathogens, it has been reported the importance of the upregulation of proinflammatory cytokines/chemokines and other inflammatory mediators, which are responsible to recruit and activate tissue resident and blood borne immune/inflammatory cells $[2,7,8]$. However, little is known about the production of such mediators and their role in the pulpal response of deciduous teeth.

In the present study, we were able to detect an upregulation in mRNA expression and protein production, by fibroblasts from primary teeth of the four different donors, of various cytokines/chemokines when these cells were challenged by EcLPS, while EfLTA only positively regulated IL-8 expression and production. These results are in agreement with the few works in the literature that have studied the production of cytokines and chemokines by these cells [22-24]. Sipert et al. and Ferreira et al. $[23,24]$ observed the upregulation of CCL3 and IL-8, respectively, only when EcLPS was tested. These cells type were also stimulated by PgLPS (Porphyromonas gingivalis lipopolysaccharide) to upregulate CCL3 production, but not CXCL12. These results reflect the different capacities of these virulence factors to initiate or maintain immune responses by deciduous pulp fibroblasts and show that although less intensely than LPS, EfLTA is able to induce HDPF to release IL-8, thus suggesting a possible participation in pulpal disease establishment or maintenance. LPS and LTA have different molecular structures and particular antigenic portions that result in different recognition pattern which will generate the specific response against that bacteria [27, 28].

Two factors are important to observe when evaluating the response profile to EcLPS challenge. The first one concerns the variation in the production intensity of the cytokines/chemokines studied. In terms of the amount produced it was possible to observe, distinct groups, despite the significant difference observed for all $(p<0.05)$. In the group in which the detected production was most intensely stimulated by EcLPS are CCL2 and IL-8, followed by IL-6. In another group in which this production was less intense are IL-4, G-CFS, GM-CSF and CCL5, followed by a group where they are detected in very low amounts (IL-1 $\beta$, IL-10, IL-12p70, IL-17A, TNF$\alpha$ and INF- $\lambda$ ).

Although the production of most of these cytokines/ chemokines by HPFD has never been studied before, the few existing studies have observed both similar and different results from those obtained in our study. While a significant increase in the production of MIP-1 $\alpha / C C L 3$ and a decrease of CXCL12 by these cells have been observed, these variations were not detected by our study $[22,23]$. Ferreira et al. 2009, as well as in our study, also detected, in supernatants from HPFD cultures challenged with EcLPS, a significant increase in the production of IL- $1 \beta$ and IL- 8 , when used as a control stimulus [24]. It is noteworthy that, while the other studies use cells from only one donor, our study is the only one that evaluates the production of cytokines by cells of four different donors, two boys and two girls, which considerably increases the reliability of the results presented, despite the expected variability among individuals.

The second concerns the kinetics of the production of these mediators. We observed that among the 18 cytokines/chemokines evaluated, 11 had their production stimulated by EcLPS mainly in the period of $6 \mathrm{~h}$ of stimulus. Of these, only five maintained high levels of production after $24 \mathrm{~h}$ of stimulation. Sipert et al. and Ferreira et al. $[23,24]$ observed some similar and some 

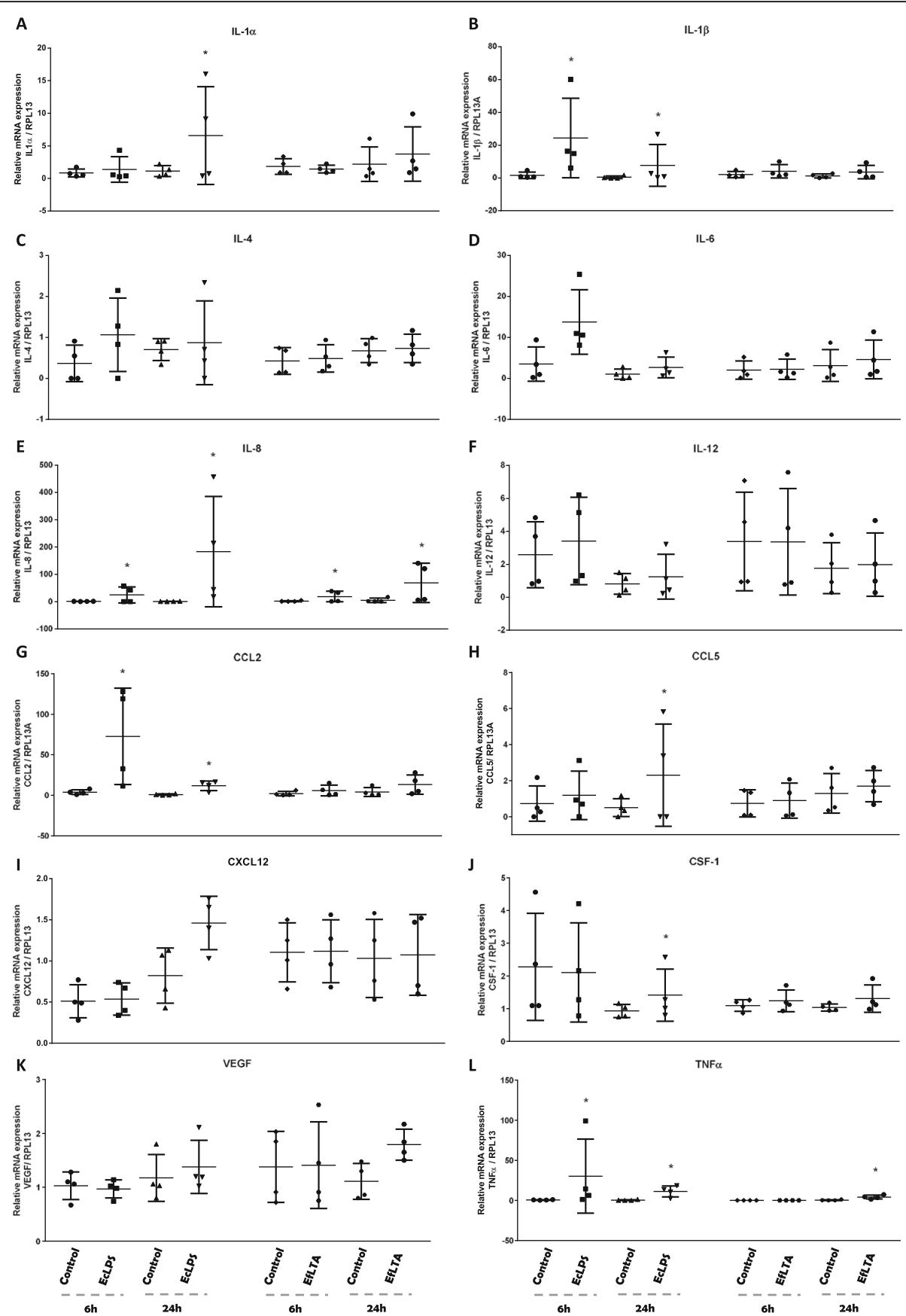

Fig. 2 qPCR analysis of cytokines/chemokines by HDPF stimulated without (Control) or with lipopolysaccharide from Escherichia coli (EcLPS) or Enterococcus faecalis lipoteichoic acid (EfLTA) $(1 \mu \mathrm{g} / \mathrm{mL}-6$ and $24 \mathrm{~h})$. Relative expression levels of the target mRNA relative to RPL13 mRNA from 4

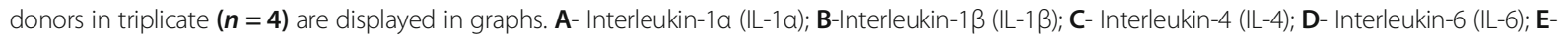
Interleukin-8 (IL-8); F- Interleukin-12 (IL-12); G- Monocyte chemoattractant protein 1 (MCP-1/CCL2); H- RANTES (CCL5); I- SDF-1 (CXCL12); J- Colonystimulating fator-1 (CSF-1); K- Vascular Endothelial Growth Factor (VEGF) and L- Tumor necrosis factor-a (TNF-a). The mean values observed for each patient are represented as a symbol and compare the stimulated values with their respective control group in the same experimental period, by nonpaired t test. * indicates significant difference in relation to respective control in the same experimental period $(p<0.05)$

different results as compared to ours, being such differences related to the EcLPS concentrations tested and cytokines evaluated. This kinetic evaluation is extremely important since it allows to identify some kind of immune response pattern against the EcLPS by this cell type, never described before, and can collaborate in the process of understanding the role of these molecules produced by these fibroblasts in 


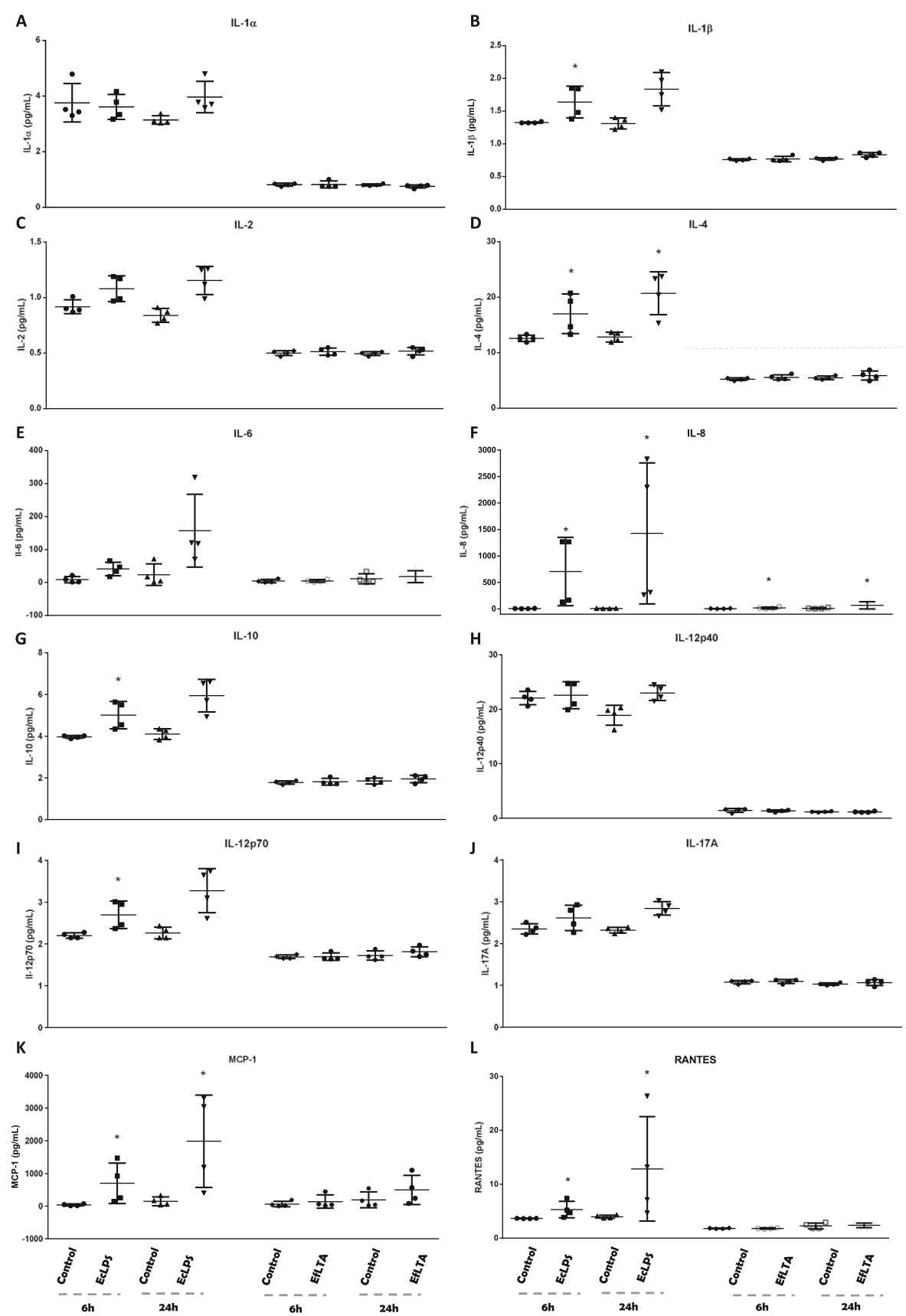

Fig. 3 - IL-1a (A), IL-1 $\beta$ (B), IL-2 (C), IL-4 (D), IL-6 (E), IL-8 (F), IL-10 (G), IL-12p40 (H), IL-12p70 (I), IL-17A (J), CCL2 (K) and CCL5 (L) protein levels in HPFD supernatants challenged, or not (Control), with Lipopolysaccharide from Escherichia coli (EcLPS) or Enterococcus faecalis lipoteichoic acid (EfLTA) for 6 and $24 \mathrm{~h}$. ELISA MILLIPLEX ${ }^{\circledR}$ was performed and the mean of a triplicate of each patient $(n=4)$ was compared using non-pared $t$ test. Each stimulated group was compared with their control in the same experimental period. * $(p<0.05)$

combating bacterial invasions of the deciduous teeth pulp.

Several cytokines had their production stimulated by EcLPS used in our study, and the role of each of them should be further evaluated. However, MCP-1/CCL2, IL8 and IL- 6 had higher levels in comparison to the others. Although increased amounts of these molecules have already been identified in pulps of inflamed permanent teeth and cultures of pulp fibroblasts of permanent teeth stimulated by other cytokines, bacterial antigens or dental materials their role in the response of deciduous pulps remains unknown [13-16]. Monocyte chemoattractant protein-1 (MCP-1/CCL2), IL-8 and IL-6 are key chemokines that regulate activation, migration 


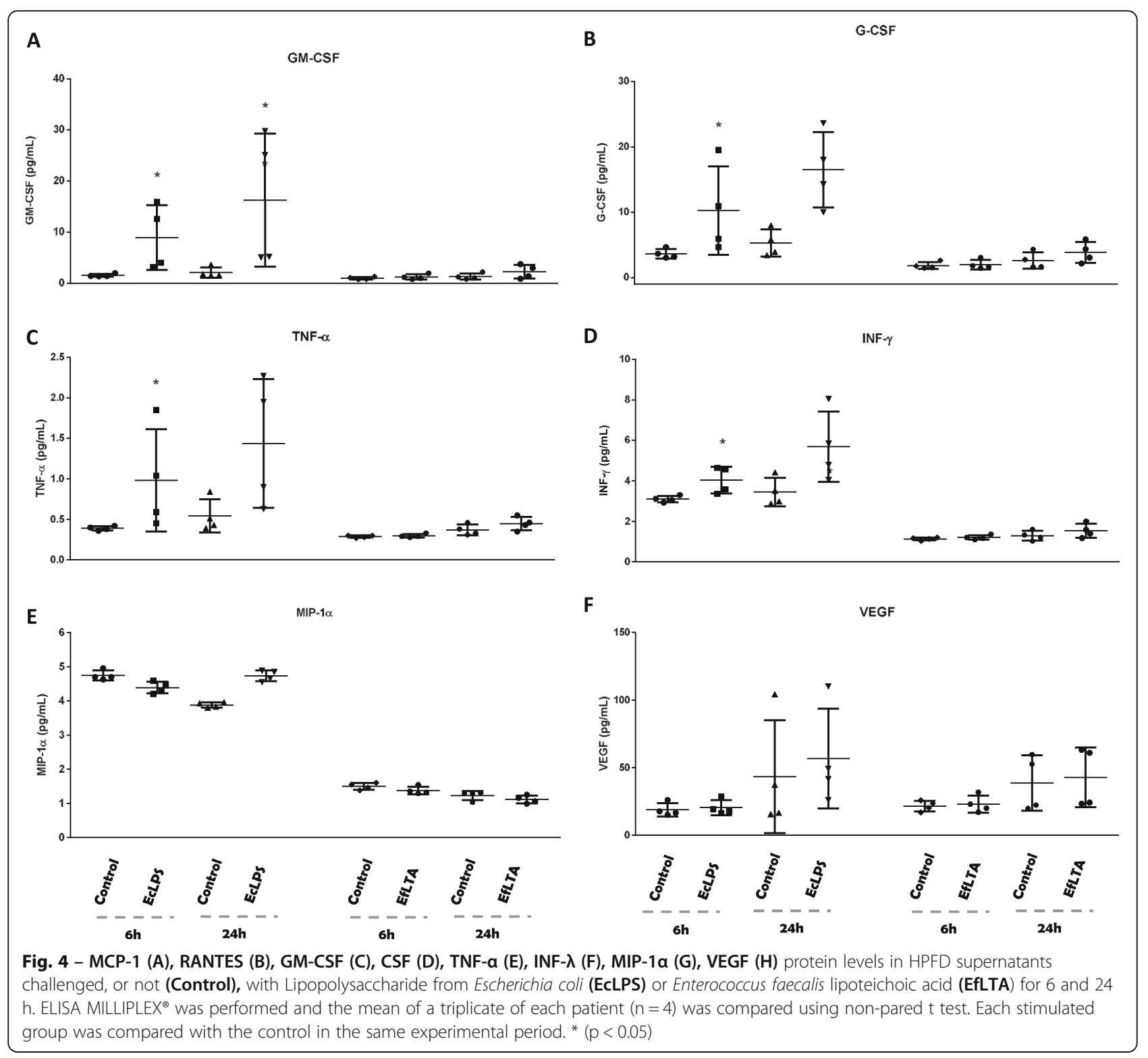

and infiltration of monocytes/macrophages, neutrophils and $\mathrm{T}$ lymphocytes from the bloodstream across the vascular endothelium required to inflammation [2, 29 ] and its influence on cell migration and angiogenesis can lead to higher regenerative potential of dental pulp [2, 30].

The results observed in our study may demonstrate the great potential that pulp fibroblasts of deciduous teeth have to contribute rapidly to the recruitment of neutrophils and lymphocytes from the vessels to the tissues affected by bacteria. Therefore, further studies using different antigens and other experimental conditions should be carried out in order to better understand the ability of HDPF to collaborate with the immune inflammatory response of the pulp against microorganisms.

\section{Conclusion}

The results of the present study confirmed our hypothesis, since pulp fibroblasts from deciduous teeth are capable of increasing gene expression and protein production after being stimulated with EcLPS and EfLTA.

\section{Supplementary information}

Supplementary information accompanies this paper at https://doi.org/10. 1186/s12865-020-00367-8.

Additional file 1: Table 1. Catalog numbers of inventoried PCR assays (Applied Biosystems, USA).

Additional file 2: Table 2. Cytokine/Chemokine detected by HCYTOMAG-60 K MILLIPLEX ${ }^{\bullet}$ Kit. 


\section{Abbreviations}

CCL2/MCP-1: Chemokine C-C motif ligand 2/monocyte chemoattractant protein 1; CCL3/MIP1-a: Chemokine C-C motif ligand 3/macrophage inflammatory protein 1-alpha; CCL5/RANTES: Chemokine C-C motif ligand 5; CSF1: Colony stimulating factor 1; CXCL12/SDF-1: C-X-C motif chemokine 12/ stromal cell-derived factor 1; DMEM: Dulbecco's modified Eagle medium; EcLPS: Escherichia coli Lipopolysaccharide; EfLTA: Enterococcus faecalis Lipoteichoic Acid; FAPESP: State of São Paulo Research Foundation; FBS: Fetal Bovine Serum; FSP-1: Fibroblast Surface Protein-1; HDPF: Human Deciduous Pulp Fibroblasts; IFN ү: Interferon-gamma; IL: Interleukin;

LPS: Lipopolysaccharide; LTA: Lipoteichoic acid; M-CSF: Macrophage colonystimulating factor; PAMPs: Pathogen-Associated Molecular Patterns; qPCR: Quantitative real-time polymerase chain reaction; TLR: Toll-like receptor; TNF-a: Tumor Necrosis Factor-alpha; VEGF: Vascular Endothelial Growth Factor

\section{Acknowledgements}

We would like to thank State of São Paulo Research Foundation (FAPESP) for the financial support through the Thematic Project and the postdoctoral fellowship (process \# 2015/03965-2 and 2016/11450-5, respectively), the National Council for Scientific and Technological Development (CNPq, process \# 307986/2017-9) and Coordenação de Aperfeiçoamento de Pessoal de Nível Superior - Brasil (CAPES) - Finance Code 001

\section{Authors' contribution}

CFS, SHPO, VSL, ASG and MAAMM conceived the ideas; BLCI, TJD, TFG and RAS collected the data; BLCI, TJD, TFG and RAS analyzed the data; and BLCl, TJD, ASG and CFS led the writing. All authors have read and approved the manuscript.

\section{Funding}

State of São Paulo Research Foundation (FAPESP) process \# 2015/03965-2 and 2016/11450-5 and the National Council for Scientific and Technological Development (CNPq, process \# 307986/2017-9). The funding was necessary to pay the reagents for the analyses, but the funding body did not take any active part in the design of the study or collection, analysis, or interpretation of data or in writing the manuscript. This study was also financed in part by the Coordenação de Aperfeiçoamento de Pessoal de Nível Superior - Brasil (CAPES) - Finance Code 001 for publication fee.

\section{Availability of data and materials}

The datasets used and/or analyzed during the current study are available from the corresponding author on reasonable request.

\section{Ethics approval and consent to participate}

All legal parents or guardians and children consented with the research (written consent). Ethical approval was obtained from the Ethics Committee for Human Research of the Bauru School of Dentistry, University of São Paulo (CAAE: 44739015.0.0000.5417).

\section{Consent for publication}

Not applicable.

\section{Competing interests}

The authors declare that they have no competing interests.

\section{Author details}

'Department of Biological Sciences, Bauru School of Dentistry, University of São Paulo, Bauru, SP, Brazil. ${ }^{2}$ Department of Surgery, Stomatology, Pathology and Radiology, Bauru School of Dentistry, University of São Paulo, Bauru, SP, Brazil. ${ }^{3}$ Department of Pediatric Dentistry, Orthodontics and Public Health, Bauru School of Dentistry, University of São Paulo, Bauru, SP, Brazil. ${ }^{4}$ Department of Basic Sciences, School of Dentistry of Araçatuba, São Paulo State University, Araçatuba, SP, Brazil. ${ }^{5}$ The Jackson Laboratory, Bar Harbor, ME, USA.
Received: 8 October 2019 Accepted: 16 June 2020

Published online: 22 June 2020

\section{References}

1. Cooper PR, McLachlan JL, Simon S, Graham LW, Smith AJ. Mediators of inflammation and regeneration. Adv Dent Res. 2011;23(3):290-5.

2. Farges JC, Alliot-licht B, Renard E, Ducret M, Gaudin A, Smith AJ, Cooper PR. Dental pulp Defence and repair mechanisms in dental caries. Mediat Inflamm. 2015;2015:230251.

3. Beutler B. Microbe sensing, positive feedback loops, and the pathogenesis of inflammatory diseases. Immunol Rev. 2009:227(1):248-63.

4. Kawai T, Akira S. The role of pattern-recognition receptors in innate immunity: update on toll-like receptors. Nat Immunol. 2010;11(5):373-84.

5. Durand SH, Flacher V, Roméas A, Carrouel F, Colomb E, Vincent C, et al. Lipoteichoic acid increases TLR and functional chemokine expression while reducing dentin formation in in vitro differentiated human odontoblasts. J Immunol. 2006 Mar 1;176(5):2880-7.

6. Durand SH, Flacher V, Romeas A, Carrouel F, Colomb E, Vincent C, et al. Lipoteichoic acid increases TLR and functional chemokine expression while reducing dentin formation in in vitro differentiated human Odontoblasts. J Immunol. 2014;176(5):2880-7.

7. Viola A, Luster AD. Chemokines and their receptors: drug targets in immunity and inflammation. Annu Rev Pharmacol Toxicol. 2008:48(1):171-97.

8. Turner MD, Nedjai B, Hurst T, Pennington DJ. Cytokines and chemokines: at the crossroads of cell signalling and inflammatory disease. Biochim Biophys Acta - Mol Cell Res. 2014;1843(11):2563-82.

9. Miggin SM, O'Neill LAJ. New insights into the regulation of TLR signaling. J Leukoc Biol. 2006 Aug:80(2):220-6.

10. Kawai T, Akira S. TLR signaling. Cell Death Differ. 2006 May; 13(5):816-25.

11. Uematsu S, Akira S. Toll-like receptors and innate immunity. J Mol Med (Berl). 2006 Sep;84(9):712-25.

12. Subaric L, Mitic A, Matvijenko V, Jovanovic R, Zivkovic D, Peric D, et al, Interleukin 1-beta analysis in chronically inflamed and healthy human dental pulp. Vojnosanit Pregl Med Pharm J Serbia. 2016;74(3):256-60.

13. Silva ACO, Faria MR, Fontes A, Campos MS, Cavalcanti BN. Interleukin-1 beta and interleukin-8 in healthy and inflamed dental pulps. J Appl Oral Sci. 2009;17(5):527-32

14. Xiong H, Wei L, Peng B. IL-17 stimulates the production of the inflammatory chemokines IL-6 and IL-8 in human dental pulp fibroblasts. Int Endod J. 2015;48(6):505-11.

15. Huang GTJ, Potente AP, Kim JW. Chugal N, Zhang X. Increased interleukin-8 expression in inflamed human dental pulps. Oral Surg Oral Med Oral Pathol Oral Radiol Endod. 1999:88(2):214-20.

16. Yang LC, Huang FM, Lin CS, Liu CM, Lai CC, Chang YC. Induction of interleukin-8 gene expression by black-pigmented Bacteroides in human pulp fibroblasts and osteoblasts. Int Endod J. 2003;36(11):774-9.

17. Pezelj-Ribaric S, Anic I, Brekalo I, Miletic I, Hasan M, Simunovic-Soskic M. Detection of tumor necrosis factor a in normal and inflamed human dental pulps. Arch Med Res. 2002;33(5):482-4.

18. Nakanishi T, Takahashi K, Hosokawa Y, Adachi T, Nakae H, Matsuo T. Expression of macrophage inflammatory protein $3 a$ in human inflamed dental pulp tissue. J Endod. 2005;31(2):84-7.

19. Adachi T, Nakanishi T, Yumoto H, Hirao K, Takahashi K, Mukai K, et al. Cariesrelated bacteria and cytokines induce CXCL10 in dental pulp. J Dent Res. 2007:86(12):1217-22.

20. Wei L, Liu M, Xiong H, Peng B. Up-regulation of IL-23 expression in human dental pulp fibroblasts by IL-17 via activation of the NF-KB and MAPK pathways. Int Endod J. 2018:51(6):622-31.

21. Sipert CR, Moraes IG, Bernardinelli N, Garcia RB, Bramante CM, Gasparoto TH, et al. Heat-killed enterococcus faecalis alters nitric oxide and CXCL12 production but not CXCL8 and CCL3 production by cultured human dental pulp fibroblasts. J Endod. 2010;36(1):91-4.

22. Sipert CR, Morandini AC d F, KC da S M, Dionisio TJ, MAAM M, SHP de O, et al. CCL3 and CXCL12 production in vitro by dental pulp fibroblasts from permanent and deciduous teeth stimulated by Porphyromonas gingivalis LPS. J Appl Oral Sci. 2013;21(2):99-105.

23. Sipert CR, Morandini AC, Dionísio TJ, Machado MAAM, Oliveira SHP, Campanelli AP, et al. In vitro regulation of CCL3 and CXCL12 by bacterial by-products is dependent on site of origin of human oral fibroblasts. J Endod. 2014 Jan;40(1):95-100. 
24. Ferreira DCD, Brito DG, Cavalcanti BN. Cytokine production from human primary teeth pulp fibroblasts stimulated by different pulpotomy agents. J Dent Child (Chic). 2009;76(3):194-8.

25. Morandini ACF, Chaves Souza PP, Ramos-Junior ES, Brozoski DT, Sipert CR, Souza Costa CA, et al. Toll-like receptor 2 knockdown modulates interleukin (IL)-6 and IL-8 but not stromal derived Factor-1 (SDF-1/CXCL12) in human periodontal ligament and gingival fibroblasts. J Periodontol. 2012;84(4):535-44.

26. Santos CF, Morandini AC, Dionísio TJ, Faria FA, Lima MC, Figueiredo CM, et al. Functional local renin-angiotensin system in human and rat periodontal tissue. PLoS One. 2015;10(8):1-26.

27. Ogawa T. Chemical structure of lipid a from porphyromonas (bacteroides) gingivalis lipopolysaccharide. FEBS Lett. 1993;332(1-2):197-201.

28. Jin MS, Kim SE, Heo JY, Lee ME, Kim HM, Paik SG, et al. Crystal structure of the TLR1-TLR2 heterodimer induced by binding of a tri-Acylated Lipopeptide. Cell. 2007;130(6):1071-82.

29. Deshmane SL, Kremlev S, Amini S, Sawaya BE. Monocyte Chemoattractant Protein-1 (MCP-1): an overview. J Interf Cytokine Res. 2009;29(6):313-26.

30. Hayashi Y, Murakami M, Kawamura R, Ishizaka R, Fukuta O, Nakashima M. CXCL14 and MCP1 are potent trophic factors associated with cell migration and angiogenesis leading to higher regenerative potential of dental pulp side population cells. Stem Cell Res Ther. 2015;6(1):1-19.

\section{Publisher's Note}

Springer Nature remains neutral with regard to jurisdictional claims in published maps and institutional affiliations.

Ready to submit your research? Choose BMC and benefit from:

- fast, convenient online submission

- thorough peer review by experienced researchers in your field

- rapid publication on acceptance

- support for research data, including large and complex data types

- gold Open Access which fosters wider collaboration and increased citations

- maximum visibility for your research: over $100 \mathrm{M}$ website views per year

At $\mathrm{BMC}$, research is always in progress.

Learn more biomedcentral.com/submissions 